Correspondence-Mr. J. A. Birds.-Prof. J. Milne.

FOREIGN PEBBLES ON OUR SOUTH COAST.

SIR,-I am not aware if the significance of the foreign stones -I do not mean, of course, the granite blocks at Pagham, but smaller pebbles of granite, porphyry, etc., occasionally occurring in the shingle of our southern coasts-has ever been remarked upon; but it has occurred to me, as no doubt to a hundred other geologists, both professional and amateur, that these are almost the only actual evidence that can be expected, in the absence of Drift and icemarkings, in favour of Dr. Croll's suggestion as to the passage of a great ice-sheet over the South-Eastern corner of England during the height of the Glacial Epoch. I have frequently observed such stones both here and at Brighton, and only within the last few days, I have picked up a variety of granites, syenites, quartz-pebbles, and porphyries (two or three dozen in all), some red sandstones, and one peculiar siliceous greenstone, the original source of which might possibly be identified. It is very inprobable that any of them are British, much more likely that they are Scandinavian. Possibly, of course, they may be parts of ballast, but I confess it seems to me much more probable that they are portions of Seandinavian drift. The evidence is slight, but it seems the only kind obtainable, and it may be taken for what it is worth.

The mass of the beach along onr south-eastern coasts, of course, consists of Chalk flints, but even these are of a very varied character, the majority being unaltered and referable at once to the original Chalk, while others bear marks of having once belonged to Eocene pebble beds (London Clay basement, Oldhaven or Bagshut). a fow to the Isle of 'Thanet Sands, and a very large proportion, as I infer from their brown coatings and sub-angular forms, to glacial gravels or drift.

J. A. Birds.

St. LeoNards-on-Sed, Oct. 16, 1880.

\title{
ON THE DISTRIBUTION OF VOLCANOS.
}

Sin,- - Having been absent during the last summer in the north part of Yezo and the Kurile Islands, it was not until a few days ago that I received your Number of May, 1880, in which there is a criticisin of a short paper of mine on the "Geographical Distribution of Volcanos," published by you in April, 1880 .

This paper was chiefly written for the purpose of pointing out a fact, which, so far as I an aware, had not previously been noticed, namely, volcanos are chiefly distributed along the borders of land which slopes STEEPLY beneath the sea.

Whilst suggesting an explanation for this $\mathrm{I}$ had reason to refer to the position of an isothermal surface lying partly under the land and partly under the sea. I then said that it was not unlikely that this surface would be found at a " much greater depth beneath the rocks which form the bed of the ocean," than the depth at which we should find it beneath the land. 
The Rev. O. Fisher pointed out to me that the greater depth could hardly be qualifed by the word " much," and with his reasoning I for the most part agree.

I should, however, like to point out that the difference in temperature beneath the land and sea bas by him, I think, been somewhat under-estimated. He takes the mean temperature of England as being $50^{\circ} \mathrm{F}$., whilst that of the sea-bottom is $32^{\circ}$.

If we remember that the greater number of active volcanic bands lie within or near the tropics, we shall be compelled to take the land temperature at something above $50^{\circ} \mathrm{F}$.

In Tokio, as recorded at the Yamato Yashiki Observatory, the mean temperature at a depth of $10 \mathrm{ft}$. is about $60^{\circ} \mathrm{F}$. Farther south it will probably be much greater. This will make the solid crust beneath the sea more nearly 2000 than $1000 \mathrm{ft}$. thicker than that beneath the land, and this as a fractional part of the zone above rocks at the melting temperature I regard as a considerable amount. Even accepting Mr. Fisher's estimate of 900 to 1080 feet, the reason I have advanced for the peculiar position of volcanos will, I think, still hold good, if not for the whole of the phenomena, at least for a considerable portion of it. JoHn Milini.

Imperiat. College of Evalveering, Tokio, JaPAN, October 10th, 1880.

\section{ON THE OLD RED SANDSTONE OF THE NORTH OF IRELAND.}

Sir,-In the November Number of the GEos. MAG. Mr. Kinahan makes some remarks on a paper of mine bearing the above title, to which I beg to make the following reply.

I am at a loss to know how Mr. Kinahan learns from the Survey Map that the Old Red Sandstone at any place "graduates" into the "fossiliferous Pomeroy Rocks." No fact is tnore clearly shown on that map than that these widely different formations are unconformable. The conglomerate in the townland of Aghafad I believe to be of Lower Silurian age.

I do not deny that there may be representatives of the Kiltorcan beds in the North of Ireland, although I have not hitherto recognized them, believing, for the reasons stated in my paper, that the "Yellow Sandstones" of that district, characterized by the occurrence of Modiola McAdami and other marine fossils, are far more probably on the horizon of the Calciferous Sandstone of Scotland, and the Carboniferous Slate and Coomhola grit of the South of Ireland. As to the position of these latter groups, I beg to refer Mr. Kinahan to Jukes's Manual of Geology, where he will find them placed as I have done-at the base of the Carboniferous Limestone, and correlated with the Calciferous Sandstone.

The word "Upper" prefixed to "Old Red Sandstone of Waterford" is simply a mistake in the abstract of my paper, which does not occur in the original.

J. Nolan.

47, Great James Street, Londonderry, November, 1880. 